\title{
Grazing dairy cows had decreased interferon- $y$, tumor necrosis factor, and interleukin-17, and increased expression of interleukin-10 during the first week after calving
}

\author{
Axel Heiser, ${ }^{* 1}$ Allison McCarthy, ${ }^{*}$ Neil Wedlock, ${ }^{*}$ Susanne Meier, $\dagger$ Jane Kay, $\dagger$ Caroline Walker, $\ddagger$ \\ Mallory A. Crookenden,‡ Murray D. Mitchell,§ Stuart Morgan,† Kate Watkins,† \\ Juan J. Loor,\# and John R. Roche† \\ *AgResearch, Hopkirk Research Institute, Grasslands Research Centre, Palmerston North, New Zealand 4442 \\ †DairyNZ Limited, Private Bag 3221, Hamilton, New Zealand 3240 \\ ‡DairyNZ Limited, School of Biological Sciences, University of Auckland, New Zealand 1010 \\ §University of Queensland, Centre for Clinical Research, Royal Brisbane \& Women's Hospital Campus, Herston, Queensland 4029, Australia \\ \#Department of Animal Sciences, University of Illinois, Urbana 61801
}

\begin{abstract}
Peripartum, and especially during the transition period, dairy cows undergo dramatic physiological changes. These coincide with an increased risk of disease during the first $2 \mathrm{wk}$ after calving and have been linked to dairy cows failing to achieve production as well as reproductive targets. Previous evidence suggests that these physiological changes affect the immune system and that transition dairy cows experience some form of reduced immunocompetence. However, almost all of these studies were undertaken in high-production, housed dairy cows. Grazing cows have much lower levels of production and this study aimed to provide clarity whether or not the dysfunctional attributes of the peripartum immune system reported in high production housed cows are evident in these animals. Therefore, cell culture techniques, flow cytometry, and quantitative PCR were applied to analyze the cellular composition of peripheral blood mononuclear cells from transition dairy cows as well as the performance of these cells in an in vitro assay. First, a combination of in vitro stimulation and quantitative PCR for cytokines was validated as a quantifiable immunocompetence assay in 29 cattle and a correlation of quantitative PCR and ELISA demonstrated. Second, the relative number of $\mathrm{T}$ helper cells, cytotoxic T cells, B cells, $\gamma \delta \mathrm{T}$ cells, natural killer cells, and monocytes in peripheral blood was measured, of which B cells and natural killer cells increased in number postcalving $(\mathrm{n}=29)$ compared with precalving. Third, following in vitro stimulation cytokine profiles indicated decreased expression of IFN $\gamma$, tumor necrosis factor, and IL-17 and increased expression of IL-10 wk 1 after calving, which later all
\end{abstract}

Received June 16, 2014.

Accepted October 27, 2014.

${ }^{1}$ Corresponding author: axel.heiser@agresearch.co.nz returned to precalving values $(\mathrm{n}=39)$. Additionally, treatment of transition cows with a nonsteroidal antiinflammatory drug (i.e., carprofen) administered on d 1,3 , and 5 postcalving $(\mathrm{n}=19$; untreated control $\mathrm{n}=$ 20) did not affect the cytokine expression at any time point. In conclusion, an immunocompetence assay has been developed that highlights a characteristic expression pattern for IFN $\gamma$, tumor necrosis factor, IL-17, and IL-10 that reflects a state of reduced immunocompetence in moderate-yielding pasture-based transition cows after calving, which is similar to that described for higher-yielding housed cows.

Key words: immunity, immunocompetence, peripartum period, transition cow

\section{INTRODUCTION}

Grazing dairy cows need to recalve annually to ensure efficient milk production from seasonal pasture production (Dillon et al., 1995; Macdonald et al., 2008). Transition from a pregnant, nonlactating to nonpregnant, lactating state exposes the animals to dramatic metabolic (Drackley et al., 2005; LeBlanc, 2010), hormonal (Laeger et al., 2013), and immunologic changes (Goff and Horst, 1997; Ingvartsen and Moyes, 2013). These changes coincide with an increased risk of disease during the first $2 \mathrm{wk}$ after calving (Overton and Waldron, 2004; Ingvartsen, 2006). The most prominent postpartum diseases are milk fever, ketosis, retained placenta, and displacement of the abomasum. Among the infectious diseases, mastitis and metritis are especially prominent, but diseases such as Johne's disease and salmonellosis also tend to become clinically apparent during the first $2 \mathrm{wk}$ after calving (Goff and Horst, 1997; Goff, 2006). Such infections can lead to permanent damage of the mammary gland, delays in conception, and result in substantial losses in milk production 
and the early culling of cows (De Vliegher et al., 2012). Recently, risk factors, including immunological events in the early postpartum period, have been linked to poor reproductive performance (Aungier et al., 2014).

Based on these observations, it has long been speculated that transition dairy cows experience some form of reduced immunocompetence. Of the immune cells affected at parturition, neutrophils have received particular interest due to their role in innate immune defense against mastitis (Gilbert et al., 1993; Madsen et al., 2002; Hammon et al., 2006; Graugnard et al., 2012). Other research has focused on lymphocyte function, primarily measuring mitogen-induced lymphocyte proliferation (Kehrli et al., 1989; Lacetera et al., 2005).

In this study, cell culture techniques, flow cytometry, and quantitative PCR have been combined to analyze the cellular composition of peripheral blood mononuclear cell (PBMC) subsets from pasture-based dairy cows as well as the performance of these cells in an in vitro assay. Performance was evaluated by analyzing the expression of mRNA encoding for selected cytokines after in vitro stimulation. Interferon- $\gamma$ is crucial for innate and adaptive immunity against viral and intracellular bacterial infections and is an important activator of macrophages (Schroder et al., 2004). Tumor necrosis factor (TNF) is a regulator of immune cells, with variable and sometimes opposing effects on a wide range of cells. Dysregulation of either IFN $\gamma$ or TNF has been associated with several diseases (Locksley et al., 2001). A cytokine that has been described to act similar to IFN $\gamma$ and synergistically with TNF, is interleukin (IL-17). It is produced by T-helper cells and increases chemokine production in various tissues to recruit monocytes and neutrophils to the site of inflammation (Jin and Dong, 2013). In contrast to these pro-inflammatory cytokines, IL-10 is considered to be an anti-inflammatory cytokine (Couper et al., 2008).

Because the failure to transition successfully seems to be associated with an inflammatory state, the use of nonsteroidal anti-inflammatory drugs (NSAID) has been investigated by several groups (Bertoni et al., 2004; Trevisi and Bertoni, 2008; Bradford and Farney, 2010; Farney et al., 2013; Priest et al., 2013). A secondary objective of this study was, therefore, to evaluate the effect of early postcalving administration of a propionic acid-derived NSAID and the immunocompetence of grazing dairy cows.

\section{MATERIALS AND METHODS}

Animals were sourced from 2 independent trials (trials 1 and 2). In the first part of this study (trial 1), an immunocompetence test was developed applying cell culture techniques, flow cytometry, and quantitative
PCR to determine the cellular composition of PBMC and the extent of immune function in peripartum cows. In the second part of the study (trial 2), the effect of administering a NSAID during the colostrum period on cellular composition and immune function was evaluated. Trial 2 was an independent study aiming to evaluate the timing of administering Carprofen on milk production, metabolic status, uterine health, and reproductive performance as reported by Meier et al. (2014). All animal manipulations were in accordance with the New Zealand Animal Welfare Act (Ministry of Primary Industries, 1999) and had approval of the Grasslands Animal Ethics Committee (Palmerston North, New Zealand) or the Ruakura Animal Ethics Committee (Hamilton, New Zealand).

For trial 1, 29 Holstein-Friesian and Holstein-Friesian $\times$ Jersey crossbred cows were enrolled from Massey University farms $\left(40.4^{\circ} \mathrm{S}, 175.6^{\circ} \mathrm{E}\right)$. These cows calved between July 18 and September 10, 2011.

For trial 2, 39 Holstein-Friesian $\times$ Jersey crossbred cows were enrolled from a single commercial farm (Whareroa Dairy Farm, Hawera, New Zealand; 39.6 ${ }^{\circ} \mathrm{S}$, $\left.174.3^{\circ} \mathrm{E}\right)$. These cows calved between July 4 and September 5, 2012. Of these cows, 12 were primiparous and 27 were multiparous.

\section{Nonsteroidal Anti-Inflammatory Treatment}

The treatment outline for trial 2 has been reported by Meier et al. (2014). Briefly, cows were allocated to 1 of 2 groups as they calved within a randomized block design (control, $\mathrm{n}=19$; NSAID treatment, $\mathrm{n}=20$ ). Control cows were not treated, whereas cows allocated to the NSAID treatment received 3 subcutaneous treatments of $1.4 \mathrm{mg} / \mathrm{kg}$ of BW of the NSAID carprofen (Carprieve LA, Norbrook Ltd., Auckland, New Zealand) on 1, 3, and 5 DIM as per instructions for appropriate use.

\section{Blood Samples and Analyses}

All cows were restrained in the race used for animal treatments. Blood was sampled on multiple days via coccygeal venipuncture at approximately $0800 \mathrm{~h}$. For trial 1, samples were taken one at $22 \pm 15 \mathrm{~d}$ before calving and again $41 \pm 16 \mathrm{~d}$ after calving. For trial 2, blood was sampled 1 to $16 \mathrm{~d}$ before calving (pre), 3 to $10 \mathrm{~d}$ (post 1), 10 to $16 \mathrm{~d}$ (post 2), and 25 to $34 \mathrm{~d}$ (post 3) after calving. Blood was collected into evacuated blood tubes containing lithium heparin as an anticoagulant (Vacutainer, Becton Dickinson, Franklin Lakes, NJ). Samples were shipped overnight to the Hopkirk Research Institute (Palmerston North, New Zealand) for further processing. 


\section{Phenotypic Analysis by Flow Cytometry}

The following antibodies were used: $\mathrm{T}$ helper cells were identified using bovine CD4 (AlexaFluor 647 conjugated, clone CC8; Bensaid and Hadam, 1991); cytotoxic $\mathrm{T}$ lymphocytes were identified using bovine CD8 (AlexaFluor 647 conjugated, clone CC63; MacHugh and Sopp, 1991); monocytes were identified using human CD14 (AlexaFluor 647 conjugated, clone TÜK4; Sopp and Howard, 1997); B lymphocytes were identified using bovine CD21 [fluorescein isothiocyanate (FITC)-conjugated, clone CC21; Naessens et al., 1990; Howard et al., 1991); cells expressing the IL-2 receptor (CD25) were identified using bovine CD25 (PE conjugated, clone ILA111; Naessens et al., 1992); natural killer (NK) cells were identified using bovine CD335 (PE conjugated, clone AKS1; Storset et al., 2004), antiovine MHC class II (PE conjugated, clone 28.1) and WC1 (FITC conjugated, clone CC101; Crocker et al., 1993; all from Abd Serotec/Bio-Rad, Hercules, CA), and anti-mouse/rat foxP3 (AlexaFluor 488 conjugated, clone FJK-16s; eBioscience, San Diego, CA; Gerner et al., 2010). For analysis, $5 \mu \mathrm{L}$ each of various antibodies were transferred into FACS-tubes; $200 \mu \mathrm{L}$ of whole blood were added and incubated for $20 \mathrm{~min}$ at room temperature in the dark. Lysis of red blood cells was performed by adding $2 \mathrm{~mL}$ of distilled water for no more than 2 min. Subsequently, $200 \mu \mathrm{L}$ of $10 \times$ PBS was added while vortexing the tubes. Samples were then centrifuged and washed twice with PBS, both at $300 \times$ $g$ for $7 \mathrm{~min}$ at room temperature. Finally, cell pellets were resuspended in $200 \mu \mathrm{L}$ of PBS and acquired and analyzed using a FACSCalibur (Becton Dickinson). A gate was drawn containing lymphocytes and monocytes based on their forward and sideward scatter characteristics. Cell subpopulations are expressed as percent positive of all cells in this gate.

\section{In Vitro Stimulation of Blood Samples}

For in vitro stimulation, $2 \mathrm{~mL}$ of whole blood was transferred to a 50-mL tube. Samples were stimulated with staphylococcal enterotoxin B (SEB; $500 \mathrm{ng} / \mathrm{mL}$ ), LPS (500 ng/mL; from Escherichia coli O111:B4), a combination of both, phytohemagglutinin $(5 \mu \mathrm{g} / \mathrm{mL})$, concanavalin A (ConA; $20 \mu \mathrm{g} / \mathrm{mL})$, pokeweed mitogen (PWM, $5 \mu \mathrm{g} / \mathrm{mL}$ ), phorbol-12-myristate-13-acetate combined with calcium ionophore $(2$ and $10 \mu \mathrm{g} / \mathrm{mL}$; all from Sigma-Aldrich, St. Louis, MO), or a preparation of inactivated bovine herpes virus (BHV-1; kindly provided by Tao Zheng, AgResearch, Palmerston North, New Zealand). For each blood sample, another $2 \mathrm{~mL}$ of whole blood was used without stimulation. Tubes were incubated at $37^{\circ} \mathrm{C} / 5 \% \mathrm{CO}_{2}$ for $22 \mathrm{~h}$. Lysis of red blood cells was performed by adding $10 \mathrm{~mL}$ of prewarmed $\left(37^{\circ} \mathrm{C}\right)$ Tris-buffered ammonium chloride lysis buffer and incubation for $10 \mathrm{~min}$ at $37^{\circ} \mathrm{C}$. Samples were centrifuged and then washed twice with PBS, both at 300 $\times g$ for 7 min at room temperature. Finally, cell pellets were resuspended in TRIzol (Invitrogen, Carlsbad, CA) and frozen at $-80^{\circ} \mathrm{C}$.

The Bovigam ELISA test kit for bovine IFN $\gamma$ (Prionics, Schlieren-Zurich, Switzerland) was used to determine the amount of IFN released into cell supernatants. The amount of IFN $\gamma$ was calculated against a standard curve prepared with recombinant IFN $\gamma$.

\section{RNA Preparation}

For the preparation of mRNA, samples were retrieved from $-80^{\circ} \mathrm{C}$ storage and quickly thawed. The phases were separated by adding $200 \mu \mathrm{L}$ of chloroform and vigorous shaking by hand for $15 \mathrm{~s}$, followed by incubation for 2 to 3 min at room temperature. Samples were centrifuged at $12,000 \times g$ for $15 \mathrm{~min}$ at $4^{\circ} \mathrm{C}$. The top aqueous layer was transferred to a fresh microcentrifuge tube and $5 \mu \mathrm{g}$ of RNase-free glycogen (Invitrogen) was added. The RNA was precipitated in the aqueous phase by addition of $500 \mu \mathrm{L}$ of $100 \%$ isopropanol followed by incubation at room temperature for $20 \mathrm{~min}$. Samples were centrifuged at $12,000 \times g$ for $15 \mathrm{~min}$ at $4^{\circ} \mathrm{C}$. The isopropanol was removed by decanting and briefly draining liquid from the inverted tube. The pellet was washed by adding $1 \mathrm{~mL}$ of $75 \%$ ethanol [ethanol in diethylpyrocarbonate (DEPC)-treated water] and centrifugation at $8,000 \times g$ for $5 \mathrm{~min}$ at $4^{\circ} \mathrm{C}$. The supernatant was tipped off and the RNA pellets air-dried for $5 \mathrm{~min}$. The RNA was dissolved in $20 \mu \mathrm{L}$ of DEPCtreated water. The RNA concentration and A260/A280 ratio were determined using a Nanodrop 1000 (Thermo Fisher Scientific, Waltham, MA). The concentration was adjusted to 0.2 to $1.0 \mu \mathrm{g} / \mu \mathrm{L}$ by adding DEPCtreated water. The RNA samples were stored at $-80^{\circ} \mathrm{C}$.

\section{DNase Treatment and DNA Preparation}

For removal of residual genomic DNA, $1 \mu \mathrm{g}$ of RNA sample was combined with $1 \mu \mathrm{L}$ of $10 \times$ DNase I buffer, $1 \mu \mathrm{L}$ of DNase I (both Invitrogen), and DEPC-treated water to $10 \mu \mathrm{L}$. Samples were centrifuged at $10,000 \times$ $g$ for 15 min at $4^{\circ} \mathrm{C}$ and incubated at room temperature for $15 \mathrm{~min}$. The DNase was inactivated by adding $1 \mu \mathrm{L}$ of $25 \mathrm{~m} M$ of EDTA, centrifugation at $10,000 \times g$ for 15 min at $4^{\circ} \mathrm{C}$, and incubation at $65^{\circ} \mathrm{C}$ for $10 \mathrm{~min}$. Samples were kept refrigerated until continuing with the reverse transcription method.

For the reverse transcription of mRNA into cDNA, $10 \mu \mathrm{L}$ of DNase I treated RNA was combined with 1 
$\mu \mathrm{L}$ of Oligo (dT) 20 primer (at $500 \mu \mathrm{g} / \mathrm{mL}=0.5 \mu \mathrm{g}$; Invitrogen) and $2 \mu \mathrm{L}$ of DEPC-treated water and incubated at $65^{\circ} \mathrm{C}$ for $10 \mathrm{~min}$. Samples were quickly cooled and centrifuged briefly to collect content. Seven microliters of reverse transcriptase Master Mix (Roche, Basel, Switzerland) was added to each reaction, mixed gently, and centrifuged briefly. Samples were incubated at $55^{\circ} \mathrm{C}$ for $30 \mathrm{~min}$ followed by prompt inactivation of the enzymes at $80^{\circ} \mathrm{C}$ for $5 \mathrm{~min}$. The DNA samples were stored at $-20^{\circ} \mathrm{C}$.

\section{Quantitative PCR}

For quantitative real-time PCR (qPCR) analysis, $10 \mu \mathrm{L}$ of SyBr Premix Ex TaqII master mixture (Takara/Clontech, Mountain View, CA), $1 \mu \mathrm{L}$ of template cDNA, $1 \mu \mathrm{L}$ of $5 \mathrm{mM}$ of each gene-specific primer, and $7 \mu \mathrm{L}$ of sterile Milli-Q water (Millipore, Billerica, MA) were combined in a $20-\mu \mathrm{L}$ reaction mixture in duplicate. Primers used were (GenBank accession numbers in parentheses): IFN $\gamma$ (NM_174086), TGATTCAAATTCCGGTGGATG TTCATTGATGGCTTTGCGC; IL4 (M77120.1), GCGTATCTACAGGAGCCACA TTGCCAAGCTGTTGAGATTC; IL-10 (NM_174088), TGCTGGATGACTTTAAGGGTTACC TCATTTCCGACAAGGCTTGG; IL-17A (NM_001008412), AACATCGTTAACCGGAGCAC GGTGGAGCGCTTGTGATAAT; TNF (AC_000173), TCCATCAACAGCCCTCTGGT TGAGGCTTGAGAAGAGGACCTGA; and U1 (AC_000164), CCATGATCACGAAGGTGGTTT ATGCAGTCGAGTTTCCCACAT.

The amplification was performed in a Rotor-Gene 6000 machine (Corbett Life Science, Mortlake, NSW, Australia). The cycle number at which the various transcripts become detectable is referred to as threshold cycle $(\mathbf{C t})$ with threshold 0.05. First, 5 cycles were eliminated using Rotor-gen 6000 series software 7.0. The threshold for detection was set to $30 \mathrm{Ct}$; anything above that is defined as not expressed. The $\mathrm{Ct}$ value with melt peak of the specific gene was validated. The mean $\mathrm{Ct}$ value of the duplicate was used for calculation of relative fold changes using the $\Delta \Delta$ Ct method (see below). As part of another study analysis (Shu et al., 2011), cytokine expression in bovine blood and tissue PCR with 3 housekeeping genes, GAPDH, ACTB, and $U 1$, were performed on 5 samples. The $\mathrm{Ct}$ values obtained from these 3 reference genes were consistent within each gene and $U 1$ had the lowest $\mathrm{Ct}$ value (Shu et al., 2011). We used $U 1$ as the reference gene for normalization and the mean $\Delta \mathrm{Ct}$ in this study; average $\mathrm{Ct}$ for $U 1$ was $18.03 \pm 0.38$, and $\mathrm{U} 1$ expression was not affected by time or treatment.
Quantitative PCR data are presented applying the comparative Ct method (Livak and Schmittgen, 2001). According to Rotor-gen 6000 series software, amplification efficiency was $1.82 \pm 0.0396(91 \%)$ for IFN $\gamma$, $1.87 \pm 0.0415(94 \%)$ for IL-10, $1.86 \pm 0.0299(93 \%)$ for IL-17, $1.85 \pm 0.0373(93 \%)$ for TNF, and $1.89 \pm 0.0264$ $(95 \%)$ for UI. $\Delta \Delta \mathrm{Ct}$ was calculated using

$$
\begin{gathered}
\Delta \Delta \mathrm{Ct}=\left(\mathrm{Ct}_{\text {gene of interest }}-\mathrm{Ct}_{\text {reference gene }}\right) \text { stimulated } \\
\text { blood }-\left(\mathrm{Ct}_{\text {gene of interest }}-\mathrm{Ct}_{\text {reference gene }}\right) \\
\text { unstimulated blood. }
\end{gathered}
$$

Results are presented as relative fold change calculated according to relative fold change $=2^{-\Delta \Delta \mathrm{Ct}}$.

\section{Statistical Analysis of Quantitative PCR}

A repeated measurements model with a variance covariance structure of autoregressive one within each cow was used to analyze the data considering treatment, day, and their interaction as fixed effects. For some responses, a transformation (natural log for IL10, IL-17, and square root for TNF) was applied to match normality assumption of the modeling. For all responses, a strong effect was found of day, but no treatment, and no interaction of treatment and day effects. Thus, the predicted means of day with pairwise comparison were produced. The analysis was performed using the packages nlme and predictmeans in $\mathrm{R}$ 3.0.0 (The R Foundation for Statistical Computing, Vienna, Austria). A $P$-value $<0.05$ was considered statistically significant.

\section{RESULTS AND DISCUSSION}

An immunocompetence test was developed based on a combination of cell culture techniques, flow cytometry, and quantitative PCR. The test allowed analysis of the cellular composition of PBMC subsets from pasturebased transition dairy cows as well as an evaluation of the function of these cells. This immunocompetence test combines and extends methods applied before (as referenced in the following). Additionally, the effects of treatment of transition cows with an NSAID were investigated.

\section{Measuring Immunocompetence in Cattle}

Stimulation in vitro of whole blood with a variety of reagents stimulated expression of IFN $\gamma$, IL-4, IL-10, and IL-17 determined by quantitative PCR (Figure 1). 
Similar whole-blood-based cultures have been used and optimized for IFN $\gamma$ assay for the detection of Mycobacterium bovis-infected cattle (Schiller et al., 2009). Primer selection for this study was based on previous work investigating cytokine profiles in mesenteric lymph nodes of cows (Shu et al., 2011). In this study, the preparation of bovine herpes virus failed to induce significant cytokine expression. All other reagents induced at least a 2.8-fold increase in the expression of cytokines investigated over unstimulated controls. The highest responses of at least 5-fold increase were achieved with a combination of SEB and LPS. Staphylococcal enterotoxin $\mathrm{B}$ is a superantigen [i.e., a class of antigens that induce oligoclonal $\mathrm{T}$ cell responses, resulting in massive cytokine release (Spaulding et al., 2013)]. In contrast to normal antigens, which activate less than $0.001 \%$ of the body's T lymphocytes, superantigens activate up to $20 \%$. Staphylococcal enterotoxin $\mathrm{B}$ has been reported to induce release of IL-2, IFN $\gamma$, and TNF in bovine blood cell cultures (Yokomizo et al., 1995) and has been used in several other studies. Lipopolysaccharide is recognized by the TLR4 receptor (Rossol et al., 2011) and has been reported to activate bovine lymphocytes (Doherty et al., 2013). To achieve high cytokine expression and allow quantification of the functional performance of bovine lymphocytes, the in vitro stimulation with a combination of SEB and LPS was used for all further experiments.

Expression of IFN $\gamma$ was compared at the mRNA level obtained by qPCR and the protein level obtained by ELISA (Figure 2). With ELISA, 1,003 $\pm 310 \mathrm{pg} / \mathrm{mL}$ secreted IFN $\gamma$ were detected after stimulation, with no differences between pre- and postcalving samples. With qPCR, a $14.6 \pm 4.9$-fold increase in IFN $\gamma$ mRNA was detected after stimulation, again with no differences between the particular pre- and postcalving sampling intervals. The combined results obtained with ELISA and $\mathrm{qPCR}$ are presented in Figure 2 and were correlated strongly $\left(\mathrm{R}^{2}=0.86\right)$. These results support the use of the combination of in vitro stimulation and $\mathrm{qPCR}$ for cytokines as a quantifiable immunocompetence test in cattle.

\section{Cellular Composition of Blood from Periparturient Cows}

Compared with laboratory animals, dairy cows are an outbred population. Consequently, the cellular composition of peripheral blood varied greatly between individual animals (Figure 3), with the size of cell subpopulations in this study varying more between individuals than has been reported in previous stud-

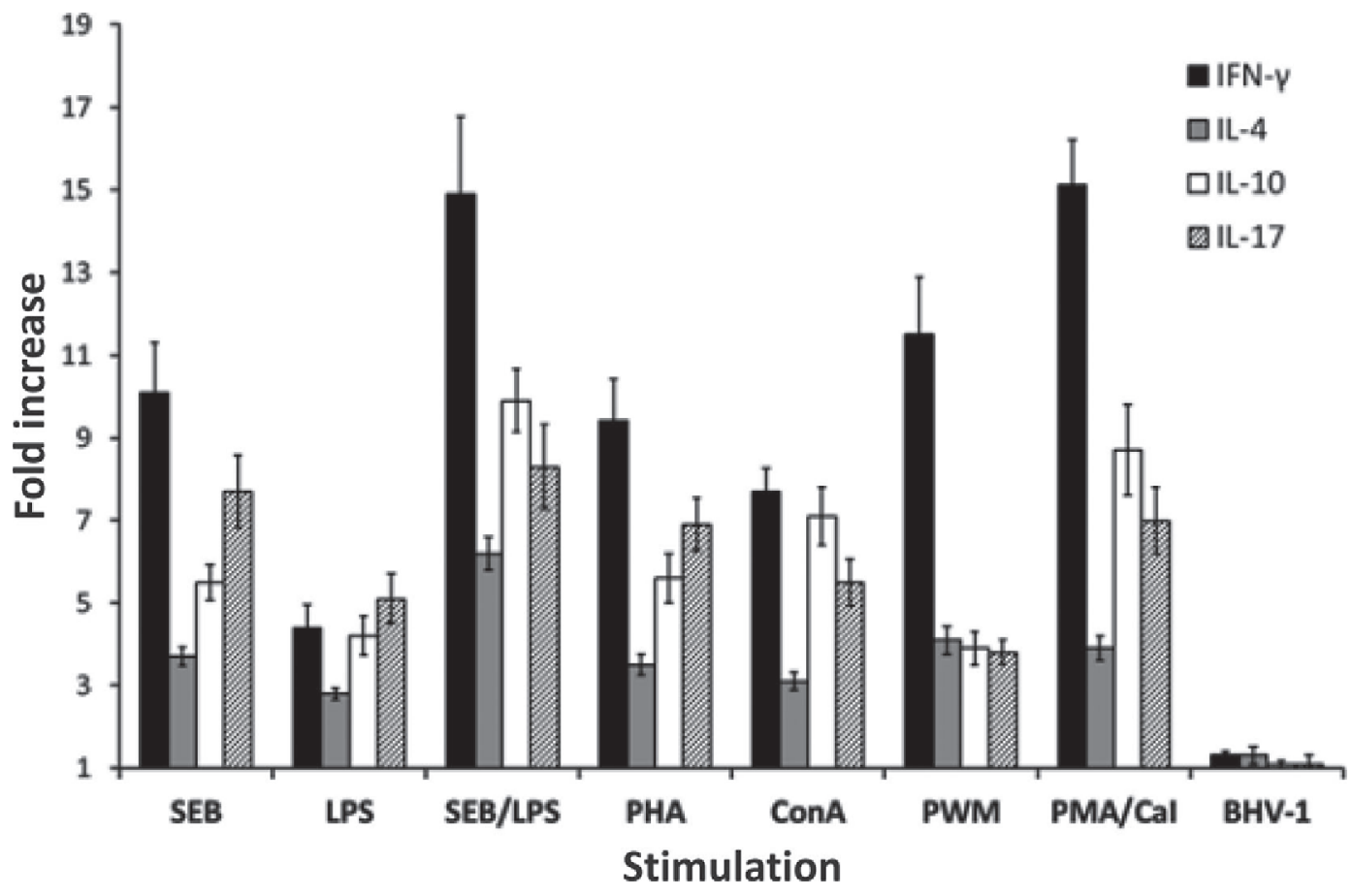

Figure 1. Increase in mRNA encoding cytokines in stimulated relative to unstimulated blood cells from dairy cows. Cells were stimulated with staphylococcal enterotoxin B (SEB), LPS, a combination of both SEB and LPS (SEB/LPS), phytohaemagglutinin (PHA), concanavalin A (ConA), pokeweed mitogen (PWM), phorbol-12-myristate-13-acetate (PMA) combined with calcium ionophore (CaI), or a preparation of inactivated bovine herpes virus (BHV-1). Columns represent mean $\mathrm{x}$-fold increase relative to the unstimulated sample \pm SE $(\mathrm{n}=29)$. 


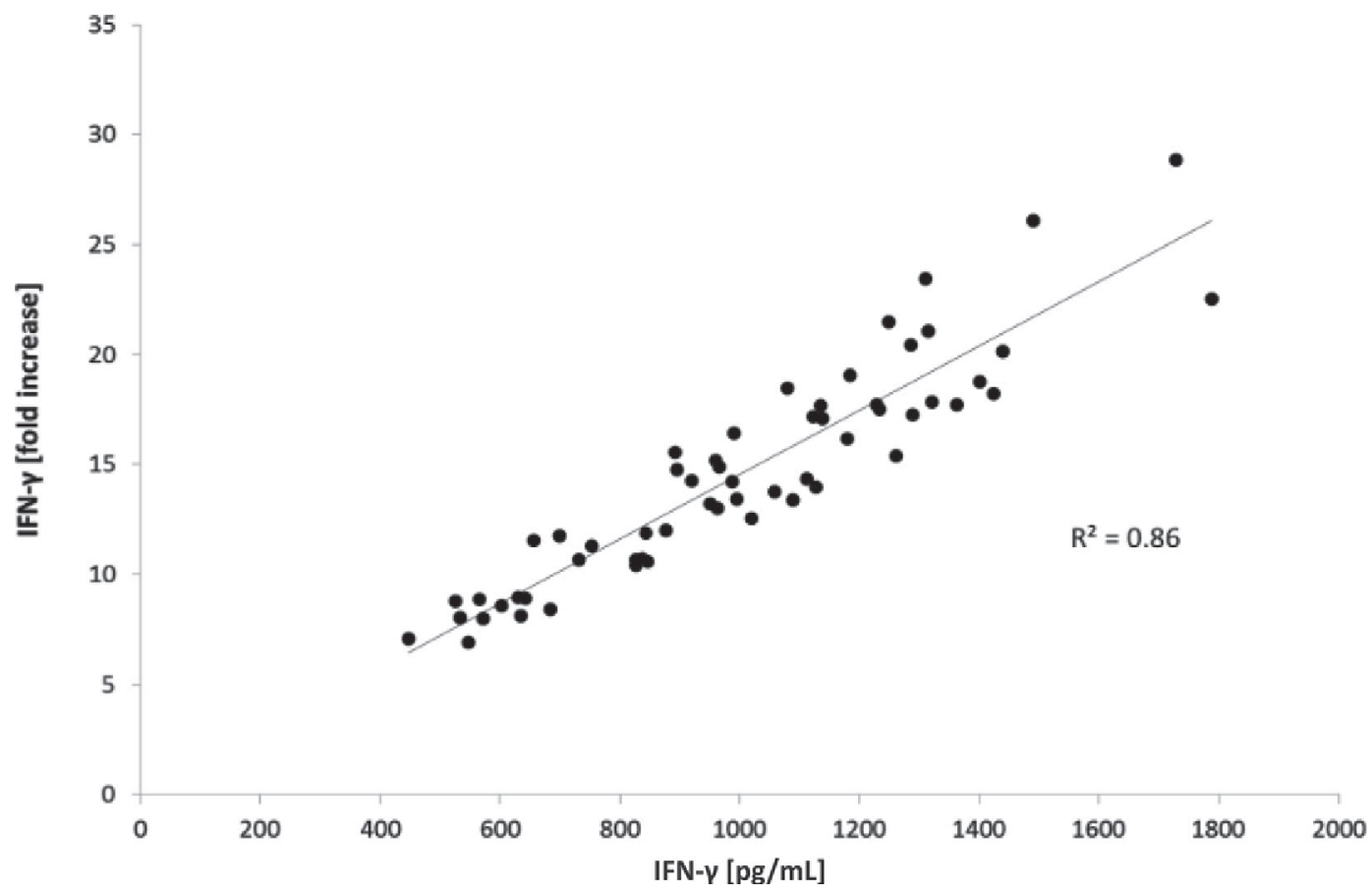

Figure 2. Correlation of IFN $\gamma$ expression analyzed at the mRNA level (quantitative PCR) and at the secreted protein level (ELISA). Results obtained with these methods correlated strongly $\left(\mathrm{R}^{2}=0.86\right.$; results from 2 sampling points $/ 29$ animals, $\left.\mathrm{n}=58\right)$.

ies (Kulberg et al., 2004; Ohtsuka et al., 2004; Doepel et al., 2006). However, the size of subpopulations also varied largely between these studies, with the between study difference almost as large as that measured in this current study. A possible explanation for this phenomenon could be the different genetic background of the herds used in these studies.

The $\mathrm{T}$ helper (CD4+) cells contributed between 1.6 and $30 \%$ of the cells extracted (mean $9.4 \%$ ), with no difference between timing of sampling relative to calving. Similarly, between 0.9 and $40 \%$ of extracted cells (mean $7.9 \%$ ) were cytotoxic T (CD8+) cells, with no significant difference between pre- and postcalving samples. Six animals had greatly increased numbers of CD8+ cells postcalving.

On average, the number of NK cell (CD335+) numbers increased $(P<0.05)$ from pre- to postcalving (from $2.9 \pm 1.5 \%$ to $6.5 \pm 2.6 \%$ ). In a recent study, elevated levels of NK cells have been reported in dairy cows with subclinical endometritis, when compared with unaffected cows (Düvel et al., 2014). Further research is required to determine if the increase in NK cell numbers across calving is associated with clinical or subclinical disease incidence (or both). One cow with a very high number (48\%) of NK cells postcalving was considered an outlier and not included in the above analysis.

For $\gamma \delta \mathrm{T}$ (WC1-positive) cells another animal was considered an outlier (showing $30 \% \gamma \delta \mathrm{T}$ cells postcalv- ing) and excluded from the analysis. The number of $\gamma \delta$ $\mathrm{T}(\mathrm{WC} 1+)$ cells did not change from pre- to postcalving $(4.9 \pm 3.1 \%)$. The B cells (CD21+) varied greatly between individual animals; whereas on average B cells increased $(P<0.05)$ from $20 \pm 14 \%$ to $45 \pm 12 \%$, some animals had declining $\mathrm{B}$ cell numbers. The relative increase in B cells can probably be explained by the requirement for the cow to produce increased antibody levels for secretion in colostrum (Stelwagen et al., 2009). The declining number of B cells in some animals could be an indicator that these animals produce fewer antibodies or a lower variety of antibody specificities. Finally, monocytes (CD14+; data not presented) were $29 \pm 11 \%$ of extracted cells, with no change in proportion between pre- and postcalving sampling times.

\section{Cytokine Profiles in Transition Dairy Cows}

Blood from dairy cows from trial 2 (NSAID treatment) was stimulated in vitro with SEB/LPS, and mRNA expression for IFN $\gamma$, TNF, IL-17, and IL-10 was analyzed by qPCR. Cytokine mRNA expression in unstimulated cells varied greatly between individual animals. No statistical evidence of treatment or time effects could be detected. To emphasize immunological function after stimulation rather than absolute values changes of cytokine mRNA expression are shown as the ratio between unstimulated cells and stimulated cells [i.e., fold change (Figure 4)]. Treatment with NSAID 

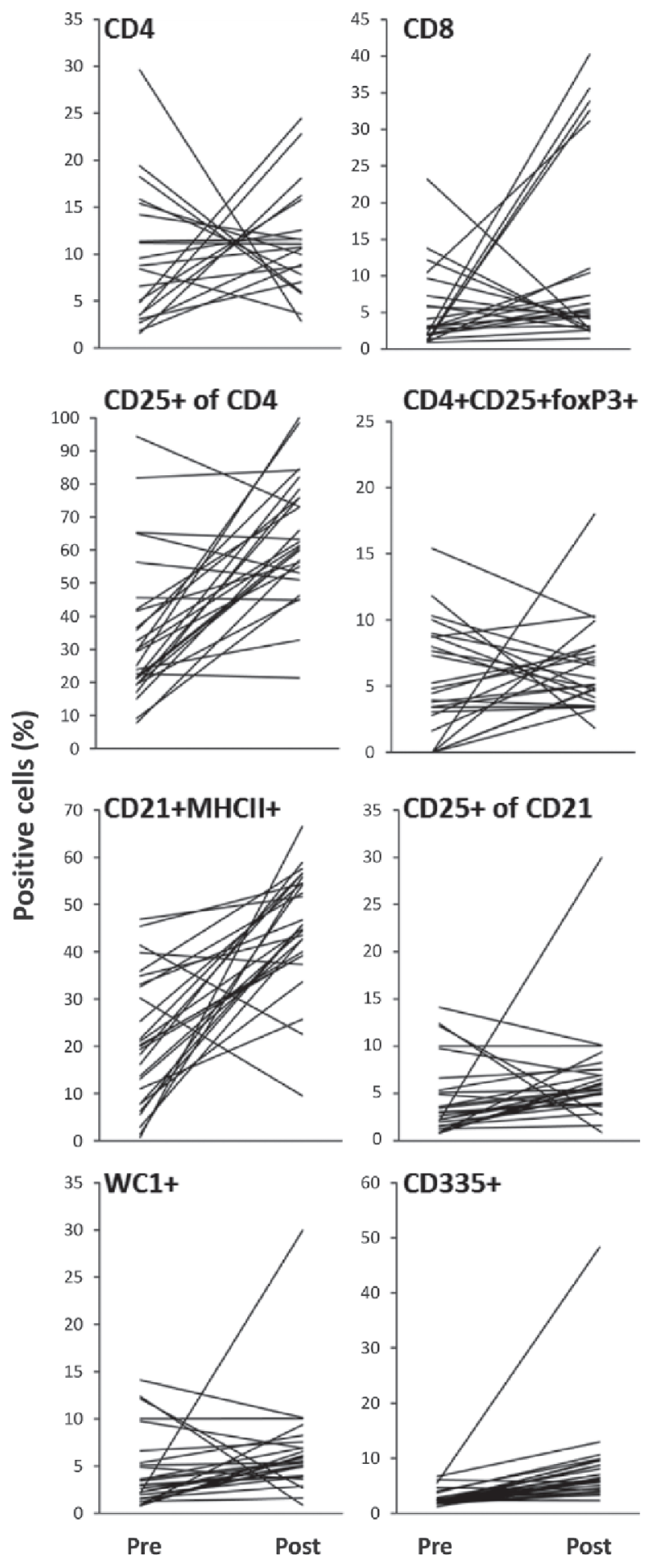

Time point

Figure 3. Cellular composition of blood from periparturient dairy cows. Blood samples from 29 dairy cows were taken $22 \pm 15 \mathrm{~d}$ before calving and $41 \pm 16 \mathrm{~d}$ postcalving and analyzed using flow cytometry for the relative number of cells expressing CD4 (T helper cells), CD8 (cytotoxic T cells), CD21 and MHC II (B cells), WC1 ( $\gamma \delta$ T cells), or CD335 [natural killer (NK) cells]. Interleukin-2 receptor (CD25) was detected on a subpopulation and can be interpreted as an activation marker. Lines represent results from individual animals. did not affect the expression of the measured cytokines at any time point. This is consistent with the lack of effect of treatment on milk production, reproduction, or circulating metabolites presented by Meier et al. (2014). Consequently, for all subsequent analysis reported here, NSAID-treated and untreated animals were combined into one group.

The changes in cytokine expression indicate a degree of reduced immunocompetence around calving lasting until approximately 3 wk after calving. Shortly after calving (post 1) IFN $\gamma$ mRNA expression was significantly reduced to 5.44-fold, from the 10.5-fold expression measured before calving $(P<0.001)$. The IFN $\gamma$ mRNA expression overshot to increased levels (post 2 compared with pre, $P<0.001$ ) before they adjusted to pre-calving levels (9.83-fold at post 3 ). A similar drop in IFN $\gamma$ secretion in wk 1 after calving was reported by others (Lessard et al., 2004). Lacetera et al. (2005) observed increased IFN expression in medium and overconditioned cows compared with thin cows 1 wk before calving but not 2 wk after calving.

In contrast, Lacetera et al. (2005) reported an increase in IFN $\gamma$ during the wk before calving in thin and medium BCS cows, which returned to normal values 2 wk after calving. Expression patterns for IL-17 were similar to IFN $\gamma$, with a reduction from 5.24-fold (pre) to 3.03 -fold (post 1; $P<0.001$ ), before overshooting to 7.06 -fold (post $2 ; P<0.001$ ) and readjustment to 5.74-fold (post 3).

Although following a similar pre- to postpartum profile of change in mRNA expression, TNF had a slower recovery to basal levels postcalving; transcription levels declined from 7.01-fold (pre) to 3.95-fold (post 1; $P<$ $0.001)$ and remained lower $(P<0.001)$ than base at post 2 (5.71-fold) and post 3 (6.15-fold). Others have reported a ConA-stimulated increase of TNF secretion in wk 1 after calving when using autologous serum but not fetal bovine serum (Lessard et al., 2004). This difference can probably be explained by different activation mechanisms of ConA and SEB: ConA is a mitogen and induces mitosis through T-cell-receptor-independent pathways, whereas SEB is a superantigen that binds to and stimulates through the $\mathrm{T}$ cell receptor.

In comparison, IL-10 had an opposite profile to the other cytokines, with expression increasing after calving (from 5.89-fold precalving to 10.88-fold at post 1), before slowly returning to the precalving level (9.33-fold at post 2 and 5.74-fold at post 3 ). In bovine cervical tissue, a 10-fold increase in IL-10 expression at parturition compared with d 185 of pregnancy has been previously reported (van Engelen et al., 2009).

Collectively, these results confirm and extend previous work. It should be noted that these previous studies used variable time points pre- and postcalving 

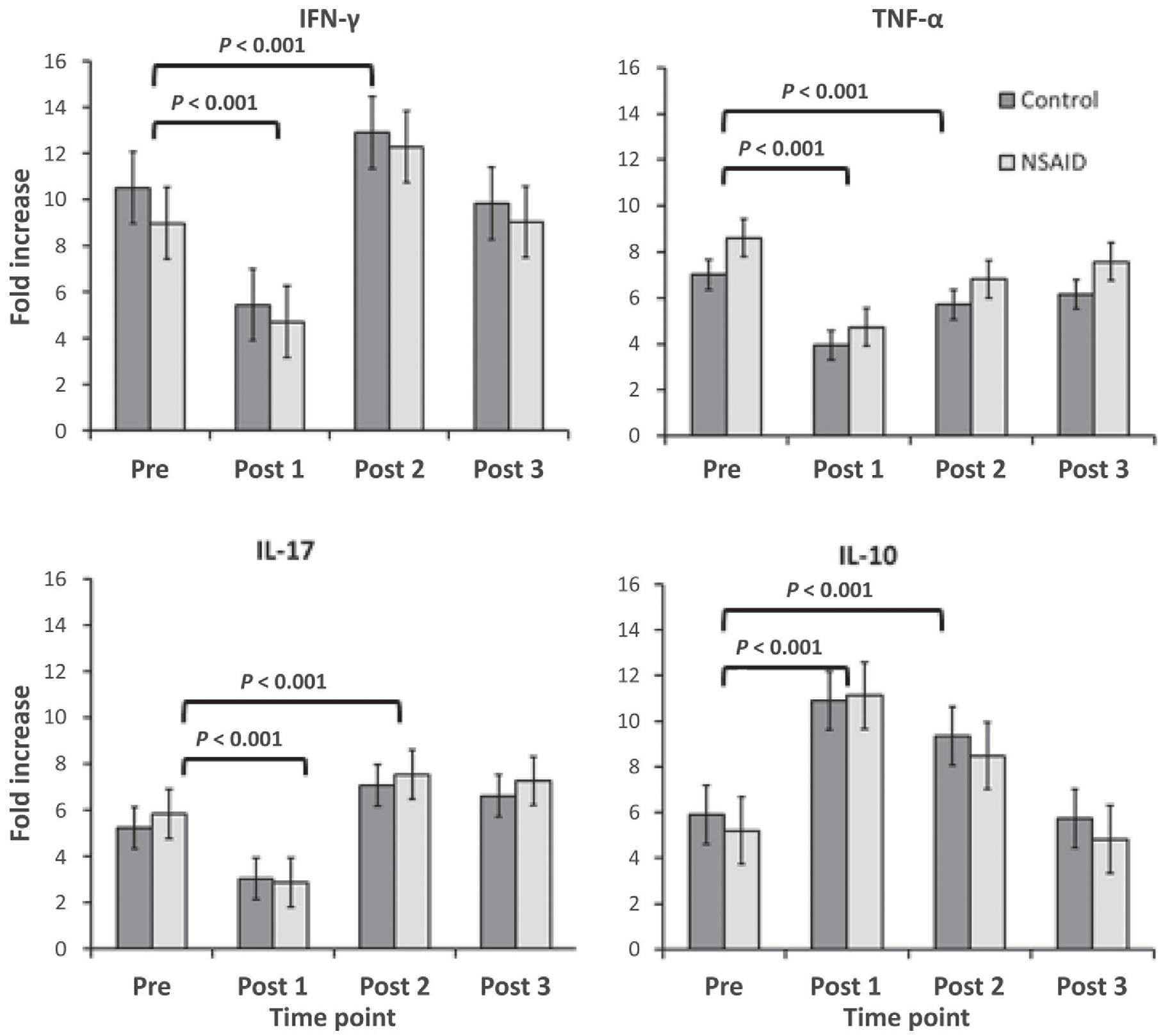

Figure 4. Increase in mRNA encoding cytokines in stimulated versus unstimulated blood cells from transition dairy cows. Columns represent results from 2 groups: untreated control $(\mathrm{n}=19)$ and animals treated with a nonsteroidal anti-inflammatory drug (NSAID; $\mathrm{n}=20) \mathrm{d} 1,3$, and 5 postcalving. Blood was sampled 1 to $16 \mathrm{~d}$ before calving (pre) and 3 to $10 \mathrm{~d}$ (post 1), 10 to $16 \mathrm{~d}$ (post 2), and 25 to $34 \mathrm{~d}$ (post 3 ) after calving. Cells were stimulated with a combination of staphylococcal enterotoxin B (SEB) and LPS; cytokine expression is quantified on the mRNA level and presented as an $\mathrm{x}$-fold increase after stimulation. Error bars indicate SE.

and either unstimulated cells or cells stimulated in vitro with a variety of reagents. However, these studies consistently report some form of reduced immunocompetence in transition cows. In postpartum cows, PBMC proliferation was reduced and secretion of IL4 depressed (Carbonneau et al., 2012), neutrophils had reduced respiratory burst (Gilbert et al., 1993; Mehrzad et al., 2001; Hammon et al., 2006) and the expression of multiple neutrophil genes was altered (Madsen et al., 2002). Nonnecke et al. (2003) reported similar effects on neutrophil function beginning during the 15 -d period before calving, with a nadir 0 to $4 \mathrm{~d}$ after calving. Recent work by Sander et al. (2011) indicates that neutrophils are less suppressed regarding phagocytosis at the time of calving than previously assumed. A decrease in phagocytic activity could be compensated by higher numbers of available neutrophils. A recent analysis of gene expression in blood cells revealed 
changes in mRNA expression of genes associated with purinergic signaling during the peripartum period; this was interpreted as cause for a reduction in cell adhesion and chemotaxis (Seo et al., 2013). Such immunological changes may be caused by or, at least, are correlated with nutritional parameters (e.g., concentration of serum NEFA; Lacetera et al., 2005; Hammon et al., 2006; Carbonneau et al., 2012; Ribeiro et al., 2013). Further analysis of additional parameters recorded within this current study may provide further insight into the mechanisms involved in immune dysfunction.

\section{CONCLUSIONS}

Applying a combination of in vitro stimulation and $\mathrm{qPCR}$ for cytokines allowed quantification of immunocompetence in transition dairy cows. A characteristic expression pattern for IFN $\gamma$, TNF, IL-17, and IL-10 suggests that the animals are immunosuppressed after calving. Further research is required to evaluate the influences of hormonal and metabolic parameters on immunocompetence and vice versa.

\section{ACKNOWLEDGMENTS}

The authors thank Fonterra (Auckland, New Zealand) and, in particular, Matt Butler and the farm staff at Whareroa Farm, Byron Taylor and the Massey University Farm staff, and Jacquie Buhler and the DairyNZ technicians involved with sample and data collection. The authors also thank Dongwen Luo (AgResearch, Palmerston North, New Zealand) for his assistance with the statistical analysis. This research was supported by New Zealand dairy farmers through DairyNZ Inc. (AN808, RD1403), by AgResearch (A19051) and the Ministry of Business, Innovation, and Employment (UOAX0814 or DRCX1201).

\section{REFERENCES}

Aungier, S. P., J. F. Roche, M. G. Diskin, and M. A. Crowe. 2014. Risk factors that affect reproductive target achievement in fertile dairy cows. J. Dairy Sci. 97:3472-3487.

Bensaid, A., and M. Hadam. 1991. Bovine CD4 (BoCD4). Vet. Immunol. Immunopathol. 27:51-54.

Bertoni, G., E. Trevisi, and F. Piccioli-Cappelli. 2004. Effects of acetyl-salicylate used in post-calving of dairy cows. Vet. Res. Commun. 28(Suppl. 1):217-219.

Bradford, B. J., and J. K. Farney. 2010. Influence of inflammation on metabolism in transition cows. Pages $65-76$ in Pages $65-76$ in Proc. 25th Annu. South-West Nutr. and Management Conf., Tempe, AZ. University of Arizona, Tucson.

Carbonneau, E., A. M. de Passillé, J. Rushen, B. G. Talbot, and P. Lacasse. 2012. The effect of incomplete milking or nursing on milk production, blood metabolites, and immune functions of dairy cows. J. Dairy Sci. 95:6503-6512.

Couper, K. N., D. G. Blount, and E. M. Riley. 2008. IL-10: The master regulator of immunity to infection. J. Immunol. 180:5771-5777.
Crocker, G., P. Sopp, K. Parsons, W. C. Davis, and C. J. Howard. 1993. 6.11 Analysis of the $\gamma / \delta$ T cell restricted antigen WC1. Vet. Immunol. Immunopathol. 39:137-144.

De Vliegher, S., L. K. Fox, S. Piepers, S. McDougall, and H. W. Barkema. 2012. Invited review: Mastitis in dairy heifers: Nature of the disease, potential impact, prevention, and control. J. Dairy Sci. 95:1025-1040.

Dillon, P., S. Crosse, G. Stakelum, and F. Flynn. 1995. The effect of calving date and stocking rate on the performance of springcalving dairy cows. Grass Forage Sci. 50:286-299.

Doepel, L., M. Lessard, N. Gagnon, G. E. Lobley, J. F. Bernier, P. Dubreuil, and H. Lapierre. 2006. Effect of postruminal glutamine supplementation on immune response and milk production in dairy cows. J. Dairy Sci. 89:3107-3121.

Doherty, R., C. O'Farrelly, and K. G. Meade. 2013. Epigenetic regulation of the innate immune response to LPS in bovine peripheral blood mononuclear cells (PBMC). Vet. Immunol. Immunopathol. 154:102-110.

Drackley, J. K., H. M. Dann, G. N. Douglas, N. A. Janovick Guretzky, N. B. Litherland, J. P. Underwood, and J. J. Loor. 2005. Physiological and pathological adaptations in dairy cows that may increase susceptibility to periparturient diseases and disorders. Ital. J. Anim. Sci. 4:323-344.

Düvel, A., J. Maaß, M. Heppelmann, J. Hussen, M. Koy, M. Piechotta, O. Sandra, D. G. E. Smith, I. M. Sheldon, I. Dieuzy-Labaye, P. Zieger, and H. J. Schuberth. 2014. Peripheral blood leukocytes of cows with subclinical endometritis show an altered cellular composition and gene expression. Theriogenology 81:906-917.

Farney, J. K., L. K. Mamedova, J. F. Coetzee, B. Kukanich, L. M. Sordillo, S. K. Stoakes, J. E. Minton, L. C. Hollis, and B. J. Bradford. 2013. Anti-inflammatory salicylate treatment alters the metabolic adaptations to lactation in dairy cattle. Am. J. Physiol. Regul. Integr. Comp. Physiol. 305:R110-R117.

Gerner, W., M. Stadler, S. E. Hammer, D. Klein, and A. Saalmüller. 2010. Sensitive detection of Foxp3 expression in bovine lymphocytes by flow cytometry. Vet. Immunol. Immunopathol. 138:154158.

Gilbert, R. O., Y. T. Grohn, P. M. Miller, and D. J. Hoffman. 1993. Effect of parity on periparturient neutrophil function in dairy cows. Vet. Immunol. Immunopathol. 36:75-82.

Goff, J. P. 2006. Major advances in our understanding of nutritional influences on bovine health. J. Dairy Sci. 89:1292-1301.

Goff, J. P., and R. L. Horst. 1997. Physiological changes at parturition and their relationship to metabolic disorders. J. Dairy Sci. 80:1260-1268.

Graugnard, D. E., M. Bionaz, E. Trevisi, K. M. Moyes, J. L. SalakJohnson, R. L. Wallace, J. K. Drackley, G. Bertoni, and J. J. Loor. 2012. Blood immunometabolic indices and polymorphonuclear neutrophil function in peripartum dairy cows are altered by level of dietary energy prepartum. J. Dairy Sci. 95:1749-1758.

Hammon, D. S., I. M. Evjen, T. R. Dhiman, J. P. Goff, and J. L. Walters. 2006. Neutrophil function and energy status in Holstein cows with uterine health disorders. Vet. Immunol. Immunopathol. 113:21-29.

Howard, C. J., W. I. Morrison, A. Bensaid, W. Davis, L. Eskra, J. Gerdes, M. Hadam, D. Hurley, W. Leibold, J. J. Letesson, N. MacHugh, J. Naessens, K. O'Reilly, K. R. Parsons, D. Schlote, P. Sopp, G. Splitter, and R. Wilson. 1991. Summary of workshop findings for leukocyte antigens of cattle. Vet. Immunol. Immunopathol. 27:21-27.

Ingvartsen, K. L. 2006. Feeding- and management-related diseases in the transition cow: Physiological adaptations around calving and strategies to reduce feeding-related diseases. Anim. Feed Sci. Technol. 126:175-213.

Ingvartsen, K. L., and K. Moyes. 2013. Nutrition, immune function and health of dairy cattle. Animal 7(Suppl. 1):112-122.

Jin, W., and C. Dong. 2013. IL-17 cytokines in immunity and inflammation. Emerg. Microbes Infect. 2:e60.

Kehrli, M. E. Jr., B. J. Nonnecke, and J. A. Roth. 1989. Alterations in bovine lymphocyte function during the periparturient period. Am. J. Vet. Res. 50:215-220. 
Kulberg, S., P. Boysen, and A. K. Storset. 2004. Reference values for relative numbers of natural killer cells in cattle blood. Dev. Comp. Immunol. 28:941-948.

Lacetera, N., D. Scalia, U. Bernabucci, B. Ronchi, D. Pirazzi, and A. Nardone. 2005. Lymphocyte functions in overconditioned cows around parturition. J. Dairy Sci. 88:2010-2016.

Laeger, T., H. Sauerwein, A. Tuchscherer, O. Bellmann, C. C. Metges, and B. Kuhla. 2013. Concentrations of hormones and metabolites in cerebrospinal fluid and plasma of dairy cows during the periparturient period. J. Dairy Sci. 96:2883-2893.

LeBlanc, S. 2010. Monitoring metabolic health of dairy cattle in the transition period. J. Reprod. Dev. 56(Suppl.):S29-S35.

Lessard, M., N. Gagnon, D. L. Godson, and H. V. Petit. 2004. Influence of parturition and diets enriched in $\mathrm{n}-3$ or $\mathrm{n}-6$ polyunsaturated fatty acids on immune response of dairy cows during the transition period. J. Dairy Sci. 87:2197-2210.

Livak, K. J., and T. D. Schmittgen. 2001. Analysis of relative gene expression data using real-time quantitative PCR and the $2^{-\triangle \Delta C T}$ method. Methods 25:402-408.

Locksley, R. M., N. Killeen, and M. J. Lenardo. 2001. The TNF and TNF receptor superfamilies: Integrating mammalian biology. Cell 104:487-501.

Macdonald, K. A., J. W. Penno, J. A. S. Lancaster, and J. R. Roche 2008. Effect of stocking rate on pasture production, milk production, and reproduction of dairy cows in pasture-based systems. J. Dairy Sci. 91:2151-2163.

MacHugh, N. D., and P. Sopp. 1991. Bovine CD8 (BoCD8). Vet. Immunol. Immunopathol. 27:65-69.

Madsen, S. A., P. S. D. Weber, and J. L. Burton. 2002. Altered expression of cellular genes in neutrophils of periparturient dairy cows. Vet. Immunol. Immunopathol. 86:159-175.

Mehrzad, J., H. Dosogne, E. Meyer, R. Heyneman, and C. Burvenich. 2001. Respiratory burst activity of blood and milk neutrophils in dairy cows during different stages of lactation. J. Dairy Res. 68:399-415.

Meier, S., N. V. Priest, C. R. Burke, J. K. Kay, S. McDougall, M. D. Mitchell, C. G. Walker, A. Heiser, J. J. Loor, and J. R. Roche. 2014. Treatment with a nonsteroidal antiinflammatory drug after calving did not improve milk production, health, or reproduction parameters in pasture-grazed dairy cows. J. Dairy Sci. 97:29322943.

Ministry of Primary Industries. 1999. New Zealand Animal Welfare Act. in Part 6. Use of animals in research, testing and teaching. Accessed Nov. 24, 2014. http://www.biosecurity.govt.nz/ legislation/animal-welfare-act/index.htm.

Naessens, J., J. Newson, N. McHugh, C. J. Howard, K. Parsons, and B. Jones. 1990. Characterization of a bovine leucocyte differentiation antigen of $145,000 \mathrm{MW}$ restricted to B lymphocytes. Immunology 69:525-530.

Naessens, J., M. Sileghem, N. MacHugh, Y. H. Park, W. C. Davis, and P. Toye. 1992. Selection of BoCD25 monoclonal antibodies by screening mouse L cells transfected with the bovine p55-interleukin-2 (IL-2) receptor gene. Immunology 76:305-309.

Nonnecke, B. J., K. Kimura, J. P. Goff, and M. E. Kehrli Jr.. 2003 Effects of the mammary gland on functional capacities of blood mononuclear leukocyte populations from periparturient cows. J. Dairy Sci. 86:2359-2368.

Ohtsuka, H., M. Koiwa, S. Fukuda, Y. Satoh, T. Hayashi, F. Hoshi, T. O. Yoshino, and S. I. Kawamura. 2004. Changes in peripheral leukocyte subsets in dairy cows with inflammatory diseases after calving. J. Vet. Med. Sci. 66:905-909.

Overton, T. R., and M. R. Waldron. 2004. Nutritional management of transition dairy cows: Strategies to optimize metabolic health. J. Dairy Sci. 87(Suppl. 1):E105-E119.
Priest, N. V., K. L. McLeod, S. McDougall, C. R. Burke, J. R. Roche, M. D. Mitchell, S. L. Greenwood, and S. Meier. 2013. The responsiveness of subclinical endometritis to a non-steroidal antiinflammatory drug in pasture-grazed dairy cows. J. Dairy Sci. 96:4323-4332.

Ribeiro, E. S., F. S. Lima, L. F. Greco, R. S. Bisinotto, A. P. A. Monteiro, M. Favoreto, H. Ayres, R. S. Marsola, N. Martinez, W. W. Thatcher, and J. E. P. Santos. 2013. Prevalence of periparturient diseases and effects on fertility of seasonally calving grazing dairy cows supplemented with concentrates. J. Dairy Sci. 96:5682-5697.

Rossol, M., H. Heine, U. Meusch, D. Quandt, C. Klein, M. J. Sweet, and S. Hauschildt. 2011. LPS-induced cytokine production in human monocytes and macrophages. Crit. Rev. Immunol. 31:379446.

Sander, A. K., M. Piechotta, G. Schlamberger, H. Bollwein, M. Kaske, A. Sipka, and H. J. Schuberth. 2011. Ex vivo phagocytic overall performance of neutrophilic granulocytes and the relation to plasma insulin-like growth factor-I concentrations in dairy cows during the transition period. J. Dairy Sci. 94:1762-1771.

Schiller, I., W. R. Waters, H. M. Vordermeier, B. Nonnecke, M. Welsh, N. Keck, A. Whelan, T. Sigafoose, C. Stamm, M. Palmer, T. Thacker, R. Hardegger, B. Marg-Haufe, A. Raeber, and B. Oesch. 2009. Optimization of a whole-blood gamma interferon assay for detection of Mycobacterium bovis-infected cattle. Clin. Vaccine Immunol. 16:1196-1202.

Schroder, K., P. J. Hertzog, T. Ravasi, and D. A. Hume. 2004. Interferon-gamma: An overview of signals, mechanisms and functions. J. Leukoc. Biol. 75:163-189.

Seo, J., J. S. Osorio, and J. J. Loor. 2013. Purinergic signaling gene network expression in bovine polymorphonuclear neutrophils during the peripartal period. J. Dairy Sci. 96:7675-7683.

Shu, D., S. Subharat, D. N. Wedlock, D. Luo, G. W. De Lisle, and B. M. Buddle. 2011. Diverse cytokine profile from mesenteric lymph node cells of cull cows severely affected with Johne's disease. Clin. Vaccine Immunol. 18:1467-1476.

Sopp, P., and C. J. Howard. 1997. Cross-reactivity of monoclonal antibodies to defined human leucocyte differentiation antigens with bovine cells. Vet. Immunol. Immunopathol. 56:11-25.

Spaulding, A. R., W. Salgado-Pabón, P. L. Kohler, A. R. Horswill, D. Y. M. Leung, and P. M. Schlievert. 2013. Staphylococcal and streptococcal superantigen exotoxins. Clin. Microbiol. Rev. 26:422-447.

Stelwagen, K., E. Carpenter, B. Haigh, A. Hodgkinson, and T. T. Wheeler. 2009. Immune components of bovine colostrum and milk. J. Anim. Sci. 87(Suppl.):3-9.

Storset, A. K., S. Kulberg, I. Berg, P. Boysen, J. C. Hope, and E. Dissen. 2004. NKp46 defines a subset of bovine leukocytes with natural killer cell characteristics. Eur. J. Immunol. 34:669-676.

Trevisi, E., and G. Bertoni. 2008. Attenuation of acetylsalicylate treatments of inflammatory conditions in periparturient dairy cows. Pages 23-37 in Aspirin and Health Research Progress. P. I. Quinn, ed. Nova Science Publishers, New York, NY.

van Engelen, E., M. W. de Groot, V. N. Breeveld-Dwarkasing, M. E. Everts, G. C. van der Weyden, M. A. Taverne, and V. P. Rutten. 2009. Cervical ripening and parturition in cows are driven by a cascade of pro-inflammatory cytokines. Reprod. Domest. Anim. 44:834-841.

Yokomizo, Y., Y. Mori, Y. Shimoji, S. Shimizu, H. Sentsui, M. Kodama, and H. Igarashi. 1995. Proliferative response and cytokine production of bovine peripheral blood mononuclear cells induced by the superantigens staphylococcal enterotoxins and toxic shock syndrome toxin-1. J. Vet. Med. Sci. 57:299-305. 